\title{
Global perspectives on teaching excellence - A new era for higher education
}

\author{
C. Broughan, G. Steventon, \& L. Clouder (Eds.), (2018). Global Perspectives on Teaching \\ Excellence: A new era for higher education ( $\mathrm{I}$ Ed.). London: Routledge.
}

Are you searching for a book that discusses teaching excellence from both a global and future perspective? In that case, Global perspectives on teaching excellence - A new era for higher education is a highly relevant and interesting book with contributions from 42 individuals, all involved in higher education in many countries. Christine Broughan, Graham Steventon and Lynn Clouder, researchers from Coventry University in the United Kingdom, are the editors. In this book, the concept of teaching excellence is explored by international authors who highlight a number of key issues. One issue is that teaching excellence has no international definition because it is such a complex subject covering diverse ontological, epistemological and cultural contexts. We can read this book with three questions in mind: If and how teaching excellence can be measured; what impact frameworks, initiatives and awards have on teaching excellence; and, what are the new challenges for global teaching excellence in the 2Ist century? The authors' focus is a blend of political, theoretical and applied research which gives the reader many different perspectives on teaching excellence.

Teaching excellence is having a growing impact on university lecturers globally and needs to be discussed from different angles. Critiques by the authors about the tendency towards a global definition include a warning. If a standardised, reductionist practice is encouraged, it is easy to forget alternative and innovative ways of teaching. However, transnational teaching can enhance educational experiences and excellence, challenging a monolithic viewpoint to be more diversified, with a greater understanding of different ways of teaching and learning. There is a global debate concerning what teaching excellence is and how it can be measured. Furthermore, who should define what it is: the teachers, the students, the stakeholders or others? Another issue is whether metrics can become too powerful and even control the teaching excellence they are supposed to measure? The content of metrics may even become a truth which leads to more of the same type of teaching and learning we are already well-accustomed to. Having been an evaluator of teaching excellence for years, this is something I have had on my mind for a long time. It is evident that metrics are a controlling factor when applying for promotions, awards or jobs, and of course in the assessment process. Have they become a writing genre? This makes authentic evidence even more important, and I would like to see more digital-technological and media-supported authentic evidence, for example in digital portfolios, to provide richer assessment material. Accurately measuring teaching excellence is not an easy task. One interesting question raised in the book is what will be considered as excellent in the future, with new global demands for excellence that will produce graduates for future jobs not yet envisioned. I wonder if our frameworks, awards and metrics are designed for innovation, creativity and taking 2Ist century skills into serious consideration or do they support more traditional forms of excellence?

The submission categories 'Articles' and 'Reflections' are peer reviewed. The other types of submissions are reviewed solely by the editorial board. See www.hogreutbildning.se

(C)2018 Annika Käck. This is an Open Access article distributed under the terms of the Creative Commons Attribution-NonCommercial 4.0 International License (https://creativecommons.org/licenses/by-nc/4.0/), allowing third parties to share their work (copy, distribute, transmit) and to adapt it, under the condition that the authors are given credit, that the work is not used for commercial purposes, and that in the event of reuse or distribution, the terms of this license are made clear.

Citation: Annika Käck (2018) 'Global perspectives on teaching excellence - A new era for higher education', Högre utbildning, 8(1), 42-43. http://dx.doi.org/10.23865/hu.v8.1238 
There are numerous national and international teaching-quality frameworks and awards, and in this book, their impact is investigated. National strategies and frameworks for developing teaching excellence are described and problematised. In some, the emphasis is on supporting institutions in their development rather than measuring them. Supporting the development of teaching excellence through institutional training and programmes is seen as something positive, with a focus on the process rather than the outcome. As mentioned in the book, there is no point in educating a future workforce in the same way as done previously. In the future, education will continue to be driven by, for example, the Internet, big data and virtual reality. These kinds of digital technology will therefore be very important. Since current curricula often relies on traditional ideas, new ones must be allowed, and that goes for teaching excellence as well. Universities want to recruit students, both locally and internationally, and give them an education to help them thrive in a global society. The book states that universities are moving towards more distance learning, being a vehicle for social mobility. In the book, it is forecasted that future teaching excellence will include being able to individualise more and more, using personalised student learning data and flexible learning environments. Furthermore, the prognoses in the book point to university lecturers teaching in teams with different roles and being more agile. Team roles, such as the collaborator, the teacher for learning, the experimenter, the scholar, the technologist and the curator are needed. One teacher can have several roles but the teaching team includes different skills. Someone might know how to personalise student data using learning pathways, while another will help students to collaborate across borders, etc. I think we already see this at some university centres for teaching and learning, but it will increase in practice. In this case, we have travelled a long way from the traditional, lonely university lecturer to coaching in teams.

Even though it is impossible to cover everything in one book, the perspective of foreign teachers, teaching at a university in a new country, who apply for promotions, awards or jobs at local universities, is lacking. These teachers can feel lonely in a different teaching culture. Their teaching excellence is assessed within an alien epistemological and cultural framework, and there is a risk of underestimating or not fully understanding their competence. Intercultural education for evaluators and university lecturers can be of help in this process. Further discussions about global perspectives on teaching excellence connected to what abilities and skills that will be needed in the future will continue, and this book is food for thought in that sense. The book is written for academic and educational policymakers, researchers and students. I highly recommend all staff involved in teaching excellence to look into this book for further discussion and development.

Annika Käck

Educational developer Centre for the Advancement of University Teaching and Dept. of Computer and Systems Sciences Stockholm University, Sweden E-mail:annika.kack@su.se 